\title{
Comparative Efficacy of Some New Chemistry Foliar Insecticides against Cotton Whitefly, Bemisia tabaci (Hemiptera: Aleyrodidae)
}

\author{
Wali Muhammad ${ }^{1 *}$, Muhammad Ammar ${ }^{2}$, Tariq Mukhtar ${ }^{3}$, Abdul Manan Hamza' \\ ${ }^{1}$ Department of Entomology, Pir Mehr Ali Shah Arid Agriculture University Rawalpindi, Pakistan \\ ${ }^{2}$ Insitute of Plant \& Environmental Protection, MNS-University of Agriculture, Multan \\ ${ }^{3}$ Department of Plant Pathology, Pir Mehr Ali Shah Arid Agriculture University Rawalpindi, Pakistan \\ Received: \\ February 10, 2021 \\ Accepted: \\ November 19, 2021 \\ Online First: \\ January 12, 2022 \\ Published: \\ June 06, 2022

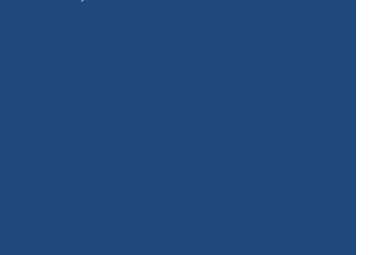

\begin{abstract}
Cotton whitefly (Bemisia tabaci) is known as the most destructive pest of vegetables, ornamentals and cotton including a wide range of weeds, forest trees and semi field crops in the world. Cotton production and area under cotton is continuously declining in Pakistan for the last five years due to a rapid proliferation of the pests. The current study was conducted to evaluate the efficacy of some new chemistry insecticides against cotton whitefly (Bemisia tabaci) during the kharif season of 2019 in a major cotton producing area of Punjab, Pakistan. A total of ten insecticides (single or mixtures) i.e. Dinotefuran + Spirotetramat $\left(\mathrm{T}_{1}\right)$, Dinotefuran + Spirotetramat $\left(\mathrm{T}_{2}\right)$, Pyriproxyfen+ Spirotetramat $\left(\mathrm{T}_{3}\right)$, Pyriproxyfen+ Spirotetramat $\left(\mathrm{T}_{4}\right)$, Spirotetramat $\left(T_{5}\right)$, Spirotetramat $\left(T_{6}\right)$, Pyrifluquinazon $\left(T_{7}\right)$, Pyrifluquinazon $\left(T_{8}\right)$, Flonicamid $\left(T_{9}\right)$, Flonicamid + Abamectin $\left(\mathrm{T}_{10}\right)$ were applied twice in a field experiment on two varieties of cotton (MNH-90 and BS-18) using randomized complete block design. Water $\left(\mathrm{T}_{0}\right)$ served as control. There were three replications of each treatment. Data for population of whitefly (nymphs and adults), natural enemies and boll weight were recorded 3, 7, 10 and 14 days after treatment of insecticides. Pyrifluquinazon @ 48.7 g/acre $\left(\mathrm{T}_{8}\right)$ caused the maximum mortality $(83 \%)$ of adults of whitefly while the maximum nymphal mortality (78.4\%) was observed in $\mathrm{T}_{8}$ (Pyrifluquinazon @ 48.7 g/acre). The maximum increase in boll weight (133\%) was observed in $\mathrm{T}_{8}$ (Pyrifluquinazon @ 48.7 g/acre) followed by $\mathrm{T}_{10}$ (Flonicamid+Abamectin) which gave 110\% increase over control. The application of Pyrifluquinazon @ 40 g/acre was found to be safer as compared with other tested insecticides with the minimum reduction of $31 \%$ in the population of natural enemies. It is therefore concluded that Spirotetramat and Pyrifluquinazon can be successfully included in IPM programs against Bemisia tabaci.
\end{abstract}

Keywords: Pyrifluquinazon, Bemisiatabaci, Cotton whitefly, Chemical control, New Chemistriy insecticides

\section{How to cite this:}

Muhammad W, Ammar M, Mukhtar T and Hamza AM, 2022. Comparative Efficacy of Some New Chemistry Foliar Insecticides against Cotton Whitefly, Bemisia tabaci (Hemiptera: Aleyrodidae). Asian J. Agric. Biol. 2022(3). DOI:

https://doi.org/10.35495/ajab.2021.02.075.
*Corresponding author email: walientomologist@gmail.com

This is an Open Access article distributed under the terms of the Creative Commons Attribution 3.0 License. (https://creativecommons.org/licenses/by/3.0), which permits unrestricted use, distribution, and reproduction in any medium, provided the original work is properly cited. 


\section{Introduction}

Cotton is an important fiber and oil seed crop of the world. It is a major source of natural fiber, edible oil and seed cake for animal feed. Approximately 250 million bales of cotton are produced annually in the world. Major cotton producing countries in the world are United States, China, Pakistan and India (Muhammad et al., 2020; Khan et al., 2020). Cotton is grown on $10 \%$ of the total cultivable area in the world which produces 250 million tons of cotton annually. About $45 \%$ of the total insecticidal application is done on cotton for the management of insect pests (Ahmad et al., 2020). Cotton production in Pakistan is lower as compared to many other countries of the world. There are many biotic and abiotic factors affecting its yield qualitatively and quantitatively.

Among biotic factors which limit cotton yield, insect pests are the major cause. About 148 species of insects including 17 major pests have been reported to feed on cotton worldwide (Abbas, 2001). Whitefly (Bemisia tabaci) is a major and destructive pest of cotton in almost all the South Asian countries like India and Pakistan (Naveen et al., 2017). Whitefly is a primary pest of cotton feeding on cell sap of tender leaves. It also hosts and transfers cotton leaf curl virus $(\mathrm{CLCuV})$. The pest is reported to damage about $60 \%$ of cotton crop causing severe yield losses (Dhillon and Sidhu, 2016). The area under cotton is continuously decreasing from the last five years due to a rapid proliferation of the pests. In Pakistan, during 2018-19, area under cotton reduced to 2.37 hectares from 2.7 million hectares of the previous year (Anonymous, 2020). Cotton whitefly damages the crop through sucking cell sap from the ventral sides of leaves, secreting honeydew which results in the development of sooty mold. The sooty mold covers the leaf surface and restricts the photosynthesis process causing lower yield (Jones, 2003; Jose and Usha, 2003; Aslam et al., 2004; Atwal and Dhaliwal, 2007).

The management of cotton whitefly is a major issue in hot and humid areas as it has many host plants to survive in the absence of cotton crop during on and off season. Different controlling methods are being used to manage the pest which include cultural control, mechanical control, biological control and chemical control (Jesse et al., 2007) but farmers mostly rely on the chemical control of whitefly (Tariq et al., 2016; Muhammad et al., 2009). The continuous and injudicious use of insecticides against whitefly is leading towards resistance development and resurgence of the pest. This is also leading towards ecological and physiological disorders for natural enemies, humans, animals and the environment (Pathania et al., 2019; Ahmad et al., 2020).

Many insecticides have been registered and recommended for the management of cotton whitefly. Among these, Flonicamid 50WG, Dinotefuran 20SG, Pyriproxyfen $10 \mathrm{EC}$ and Diflubenzuron 50WP are new chemistry insecticides and have been recently released (Pathania et al., 2020). Very little information is available in the country on the effectiveness of these insecticides against whitely and other insect pests. In the present study, efficacy of some new chemistry insecticides recently released in the market was tested against whitefly, the most damaging insect pest of cotton. The study will help in replacing the traditional old insecticides with the new chemistry insecticides to minimize environmental pollution.

\section{Material and Methods}

The effectiveness of new chemistry insecticides (Table 1) was evaluated in a farmer field on two cotton varieties (MNH-90 and BS-18) which were sown during the first week of April, 2019. The experiment was conducted in randomized complete block design with three replications of each treatment. Each experimental unit (block) measured $100 \mathrm{~m}^{2}$. All the standard cultural practices were applied except plant protection measures. After 120 days of crop sowing, the natural population of whitefly was counted before spraying of insecticides and was found on its peak (above ETL). Knapsack sprayer (power operated) equipped with hollow cone nozzle was used for foliar application of selected insecticides. Sprayer was calibrated before each application. One hundred and forty liters of water was used for one acre for insecticide application after calibration of sprayer. The selected insecticides and their doses are mentioned in Table 1.

For estimation of whitefly population (nymphs and adults/leaf) from each sampling unit from each replication, 15 leaves (upper, middle and lower) were selected from randomly selected plants. 
Wali Muhammad et al

Table-1: Details of treatments applied against whitefly in cotton crop

\begin{tabular}{|c|c|c|c|c|c|}
\hline $\begin{array}{l}\text { Trt. } \\
\text { No. }\end{array}$ & Brand Name & Active Ingredients & $\begin{array}{l}\text { Distributor in } \\
\text { Pakistan }\end{array}$ & $\begin{array}{l}\text { Dose/A } \\
\text { (g/ mL) }\end{array}$ & Cost/Spray (Rs.) \\
\hline $\mathrm{T}_{0}$ & Control & - & - & - & - \\
\hline $\mathrm{T}_{1}$ & \multirow[b]{2}{*}{$\begin{array}{l}\text { Oshin } 20 \% \text { SG+ } \\
\text { Movento } 240 \text { SC }\end{array}$} & Dinotefuran + Spirotetramat & \multirow{2}{*}{$\begin{array}{c}\text { Arysta Lifescience } \\
\text { Pakistan (Pvt) Ltd } \\
+ \\
\text { Bayer Crop } \\
\text { Sciences, Pakistan }\end{array}$} & $30+30$ & 3565 \\
\hline $\mathrm{T}_{2}$ & & Dinostefuran + Spirotetramat & & $40+40$ & 4753 \\
\hline$T_{3}$ & \multirow{2}{*}{$\begin{array}{c}\text { Pyriproxyfen } 10.8 \\
\% \text { EC + } \\
\text { Movento240 SC }\end{array}$} & Pyriproxyfen+ Spirotetramat & \multirow{2}{*}{$\begin{array}{c}\text { Jaffar Agro } \\
\text { Services (Pvt.) Ltd } \\
\text { + Bayer Crop } \\
\text { Sciences, Pakistan }\end{array}$} & $16+32$ & 2348 \\
\hline $\mathrm{T}_{4}$ & & Pyriproxyfen+ Spirotetramat & & $20+40$ & 2935 \\
\hline $\mathrm{T}_{5}$ & Movento240 SC & Spirotetramat & \multirow{2}{*}{$\begin{array}{c}\text { Bayer Crop } \\
\text { Sciences, Pakistan }\end{array}$} & 30 & 1840 \\
\hline $\mathrm{T}_{6}$ & Movento240 SC & Spirotetramat & & 38.4 & 2355 \\
\hline $\mathrm{T}_{7}$ & \multirow{2}{*}{ Matoi20\% WG } & Pyrifluquinazon & \multirow{2}{*}{$\begin{array}{c}\text { Jaffar Agro } \\
\text { Services (Pvt.) Ltd } \\
\end{array}$} & 40 & 3800 \\
\hline $\mathrm{T}_{8}$ & & Pyrifluquinazon & & 48 & 4560 \\
\hline $\mathrm{T}_{9}$ & Ulala50 WG & Flonicamid & $\begin{array}{l}\text { ICI, Pakistan Pvt. } \\
\text { Ltd }\end{array}$ & 40 & 2380 \\
\hline $\mathrm{T}_{10}$ & Big Hit $10.7 \%$ WG & Flonicamid+Abamectin & $\begin{array}{l}\text { Kanzo, AG.Pvt. } \\
\text { Ltd }\end{array}$ & $28.5+3.6$ & 2800 \\
\hline
\end{tabular}

Before treatment, data on whitefly population were recorded and $1^{\text {st }}$ application was made on the same day. The whitefly nymphs and adults were recorded 3 and 7 days after insecticidal application. The second application of insecticides was made using the same volume and dosage. In the control plot, only water was sprayed at the same volume. After $2^{\text {nd }}$ treatment, data were recorded 3, 7, 10 and 14 days after treatment. Mean population of whitefly was recorded from all the six observations after treatment and corrected mortality (\%) was calculated. The experiment was repeated after normalization of the natural whitefly population and results were pooled. The corrected percent mortality was calculated using the Henderson and Tilton's (1955) equation given below

$$
\text { Corrected } \%=\left(1-\frac{\mathrm{n} \text { in Co before treatment } * \mathrm{n} \text { in } \mathrm{T} \text { after treatment }}{\mathrm{n} \text { in Co after treatment } * \mathrm{n} \text { in T before treatment }} \times 100\right.
$$

Where: $\mathrm{n}=$ Whitefly population, $\mathrm{T}=$ treated, $\mathrm{Co}=$ control

Data regarding natural enemies/plant and average boll weight per plant was also recorded in each observation and increase or decrease over control was calculated as described below:

Increase or decrease over control $=$ Treated-Control/Control $\times 100$.
Computer based analytical software; Statistix 8.1 was used for analysis (Analytical software, 2005). The data of whitefly population (adults/nymphs) after $3,7,10$ and 14 days of treatment were subjected to analysis of variance through two-way factorial (mean corrected mortality). Means were separated using Tukey's HSD $(\alpha=0.05)$.

\section{Results and Discussion}

\section{Effect of insecticides on percent mortality}

The analysis of variance showed highly significant results regarding effect of insecticides on percent mortality of whitefly. The maximum percent corrected mortality (83.6\%) of whitefly adults was observed after the treatment of Pyrifluquinazon @ $48.7 \mathrm{~g} /$ acre $\left(\mathrm{T}_{8}\right)$ in MNH-90 plot followed by Spirotetramat @ 38.47g/ acre $\left(\mathrm{T}_{6}\right)$ in BS-18 plot (Figure 1). The minimum adult mortality was found in $\mathrm{T}_{10}$ (Flonicamid+Abamectin) in $\mathrm{MNH}-90$ plot followed by the same treatment in BS-18 plot showing $68.5 \%$ and $69.8 \%$, mortalities respectively (Figure 1). The nymphal mortality $(78.4 \%)$ was the maximum in $\mathrm{T}_{8}$ (Pyrifluquinazon @ 48.7g/acre) in BS-18 plot followed by $79.7 \%$ mortality in $\mathrm{T}_{2}$ (Dinotefuran+ Spirotetramat @ $40+40$ g/acre) as shown in Figure 2. The minimum nymphal mortality was observed in $\mathrm{T}_{10}$ (Flonicamid+Abamectin) in BS18 plot followed by $\mathrm{T}_{9}$ (Flonicamid) in $\mathrm{MNH}-90$ plot showing $46.5 \%$ and $47.4 \%$, decreases respectively 
(Figure 2). The overall adult and nymphal mortality was higher in BS-18 variety of cotton as compared to MNH-90. These results reveal that Pyrifluquinazon has the ability to control adult cotton whitefly and its nymphal stage (Smith and Nagle, 2017).

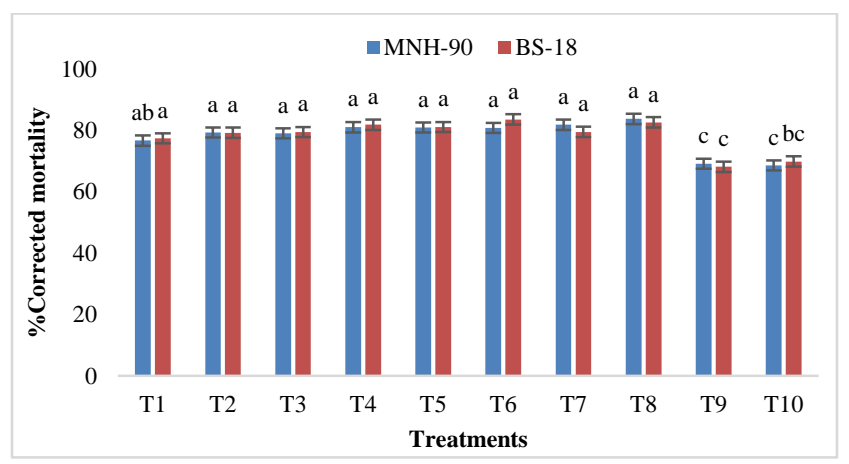

Figure-1: Corrected mortality (\%) of adult whitefly due to insecticide application (mean of post treatment observations), 2019.

On the other hand, Spirotetramat showed ability to control whitefly adults but found weaker against nymphal stage of the pest as compared with Pyrifluquinazon and the findings were in accordance with those of Salazar-López et al. (2016). However, when spirotetramat was mixed with the Dinotefuran, it performed better to control nymphal stage of whitefly (Figure 1 and 2). Similarly, in this study many effective insecticides have shown lesser efficacies against whitefly. Many earlier studies confirmed the present findings which reported that Pyrifluquinazon had the ability to control immature and mature stages of whitefly and mites on greenhouse crops (Kumar et al., 2016). Kadam et al. (2014) found dinotefuran 20 SG effective against $B$. tabaci. Das and Islam (2014) reported that pyrifluquinazon was most effective ( $87 \%$ mortality) against whitefly as compared to other insecticides. Magsi et al. (2017) confirmed that most of the insecticides caused mortality of whitefly from $78 \%$ to 93\% when appropriate amount of water was used. McLeod and Rashid (2014) also reported the effectiveness of pyrifluquinazon against greenhouse whitefly on tomato crop. The repetitive and injudicious use of same insecticide on crops may reduce the susceptibility of whitefly to already recommended insecticides (Pathania et al., 2020).

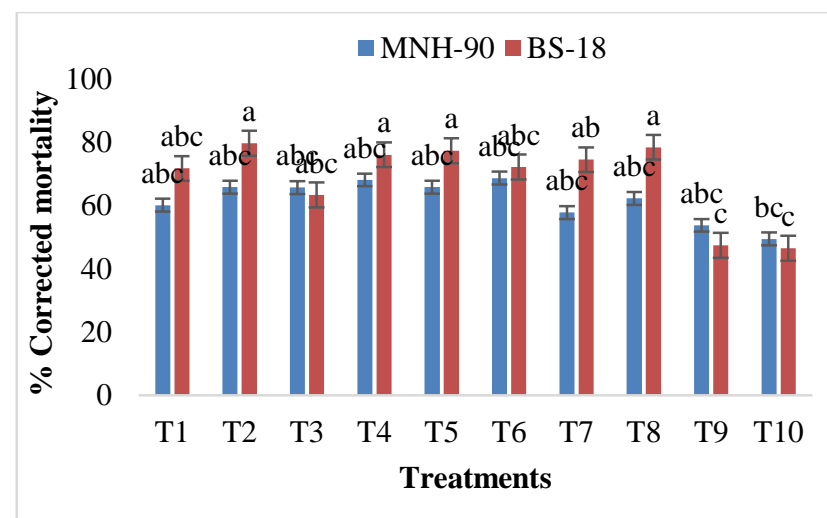

Figure-2: Corrected mortality (\%) of whitefly nymphs due to insecticide application (mean of post treatment observations), 2019.

\section{Effect on whitefly population}

All the insecticides and their mixtures gave similar results on the population of whitefly when repeated after one week. The maximum reduction in the population was observed after 14 days, afterwards the population started to increase in all the treatments without any significant statistical difference (Figure 3 and 4). The individual effects of insecticides on whitefly populations were also nonsignificant in case of varieties (Figure 3 and 4). However, the overall population of whitefly (nymph + adult) was higher on MNH-90 (above 20-35/leaf) as compared to those on BS-18 showing 15-13/leaf (Figure 3 and 4).

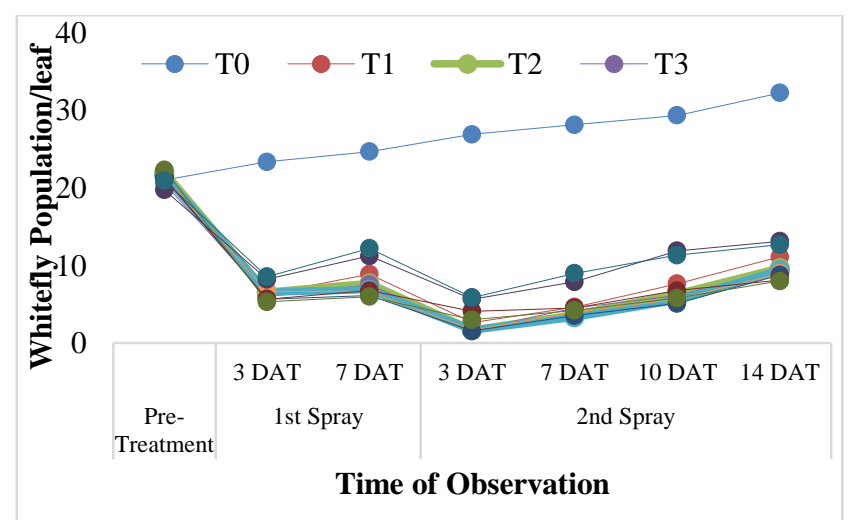

Figure-3: Pre-treatment and post-treatment of white fly (adult + nymph) population on MNH-90 cotton variety (pooled means of two experiment), DAT=days after treatment 


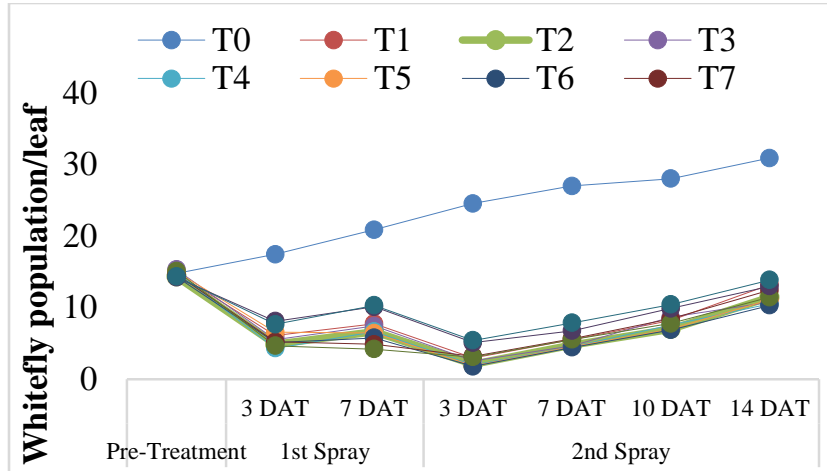

Time of observation

Figure-4: Pre-treatment and post-treatment of white fly (adult + nymph) population on BS-18 cotton variety (pooled means of two experiment), DAT=days after treatment

It was also observed that population of whitefly remained below ETL till $14^{\text {th }}$ day. Similar responses of different insecticides against whitefly adults and nymphs were also reported previously by many researchers as revealed in this study. Smith and Giurcanu (2013) reported that Pyrifluquinazon remained effective against tomato whitefly nymphs and adults upto14 days after treatment. The different response of insecticides on the population of whitefly on different varieties might be due to the response of different plant characteristics to pests as mentioned in earlier studies (Tsai and Wang, 2001; Liu et al., 2004: Akkopru et al., 2015). Smith and Nagle (2017) reported the efficacy of pyrifluquinazon for seven days which corroborated our findings that application of insecticides for whitefly management should be repeated after 7 days for more consistent control.

\section{Effect on boll weight}

All the insecticides applied for the management of whitefly resulted in an increase in boll weight (no. of bolls/plant $\times$ single boll weight $(\mathrm{g})$ over control (Figure 5). The maximum increase in boll weight $(133 \%)$ was observed in $\mathrm{T}_{8}$ (Pyrifluquinazon @ $48.7 \mathrm{~g} /$ acre) followed by $\mathrm{T}_{10}$ (Flonicamid+Abamectin) which gave an increase of $110 \%$ over control. The minimum increase $(20 \%)$ in boll weight was observed in $\mathrm{T}_{4}$ (Pyriproxyfen @ $20 \mathrm{~mL}+$ Spirotetramat @ 40g) followed $\mathrm{T}_{5}$ (Spirotetramat @ 30g) showing 31\% increase (Figure $5)$. The findings reported in this paper verified the earlier results that application of insecticides had impact on boll size and weight of cotton crop resulting in an increase in yield (Gonias et al., 2008).
Similarly, Abbas et al. (2016) reported an increase in boll weight over control after treatment of Flonicamid which also supported our results. However, the study of Youngman et al. (1990) did not support our findings due to phytotoxic effects of older insecticides but in the present study new chemistry insecticides were used which cause increase in boll weight.

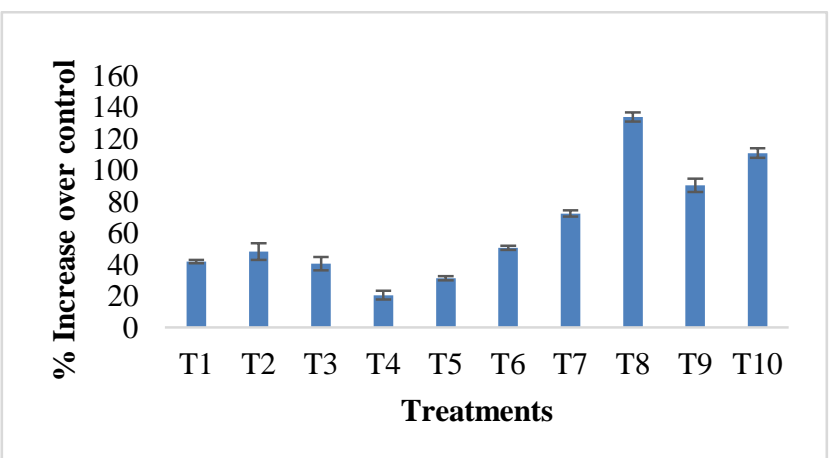

Figure-5: Effect of insecticides application on percent increase over control of boll weight (Mean \pm SE)

\section{Effect on natural enemies}

The application of insecticides on natural enemies had significant effects. All the insecticides significantly reduced populations of natural enemies over control (Figure 6). The minimum decrease (31\%) in natural enemies was observed with $\mathrm{T}_{7}$ (Pyrifluquinazon @ $40 \mathrm{~g}$ ) followed by the $41 \%$ decrease in $\mathrm{T}_{8}$ (Pyrifluquinazon @48g) as shown in Figure 6. The maximum reduction (74\%) was observed in $\mathrm{T}_{2}$ (Dinotefuran+ Spirotetramat @ $40 \mathrm{~g}$ of each) followed by the $60 \%$ reduction in $\mathrm{T}_{4}$ (Pyriproxyfen@20mL+Spirotetramat@40g) as shown in Figure 6. The overall reduction in the population natural enemies ranged from $31 \%$ to $74 \%$. Many earlier studies also reported reductions in the populations of natural enemies after the application of insecticides. Bacci et al. (2007) reported the minimum reduction in natural enemies with the application of abamectin. Das and Islam (2014) reported $16 \%$ reduction in the population of natural enemies after spraying dinotefuran but in the present study, it was higher which might be due to change of spraying machinery or volume of water used for spray. Similarly, El-Wakeil et al. (2013) reported that almost all the insecticides have negative effect on natural enemies but pyriproxyfen had less severe effect than other insecticides as was revealed in current study. 


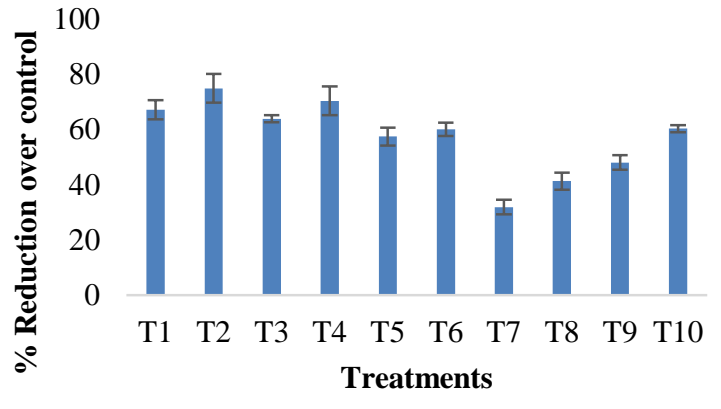

Figure-6: Effect of insecticides application on percent decrease over control of natural enemies' population (Mean $\pm \mathrm{SE}$ )

\section{Conclusion}

Spirotetramat and pyrifluquinazon were found to be the most effective insecticides against whitefly when sprayed at recommended dose with reasonable amount of water. Pyriproxyfen was found relatively safer for natural enemies. Foliar application of pyrifluquinazon also resulted in increase in crop yield by controlling both adults and nymphs of cotton whitefly and had less effect in the reduction of natural enemies.

\section{Acknowledgement}

The authors are thankful to team of Pest Warning and Quality Control of Pesticides Wing of Agriculture Department, Government of Punjab for providing the idea and task to complete this trial.

Disclaimer: None.

Conflict of Interest: None.

Source of Funding: None.

\section{References}

Abbas G, Ahmed A, Amer M and Abbas Z, 2016. Comparative efficacy of pesticides against sucking insect pest of cotton (Gossypium hirsutum L.) crop under arid condition. Sci. Int. 28(3): 2679-2682.

Abbas MA, 2001. General Agriculture. Emporium publication (2nd edition), Pakistan. pp. 352.

Ahmad M, Muhammad W and Sajjad A, 2020. Ecological Management of Cotton Insect Pests. In: Ahmad S., Hasanuzzaman M. (eds) Cotton Production and Uses. Springer, Singapore. https://doi.org/10.1007/978-981-15-1472-2_12
Akkopru EP, Atlihan R, Okut H and Chi H, 2015. Demographic assessment of plant cultivar resistance to insect pest: a case study of the dusky veined walnut aphid (Hemiptera: Callaphididae) on five walnut cultivars. J. Econ. Entomol. 108:1-10.

Anonymous, 2020. Farmers fear further decline in cotton production. https://tribune.com.pk/story/2053083/farmers-feardecline-cotton-production.

Aslam M, Razaq M, Shah SA and Ahmad F, 2004. Comparative efficacy of different insecticides against sucking pests of cotton. J. Res. Sci. 15: 53-58.

Atwal AS and Dhaliwal GS, 2007. Agricultural pests of South Asia and their management. Kalayani Publishers, New Delhi. pp. 505.

Bacci L, Crespo AL, Galvan TL, Pereira EJ, Picanço MC, Silva GA and Chediak M, 2007. Toxicity of insecticides to the sweetpotato whitefly (Hemiptera: Aleyrodidae) and its natural enemies. Pest. Manage. Sci. 63(7): 699-706. https://doi.org/10.1002/ps.1393

Das G and Islam T, 2014. Relative efficacy of some newer insecticides on the mortality of jassid and white fly in brinjal. Int. J. Biol. Sci. 4(3):89-93.

Dhillon BS and Sidhu RS, 2016. Successful management of whitefly incidence in cotton through joint efforts of farm experts and farmers. Progress. Farm. 52:5-7.

El-Wakeil N, Gaafar N, Sallam A and Volkmar C, 2013. Side effects of insecticides on natural enemies and possibility of their integration in plant protection strategies. Insecticides: Development of Safer and More Effective Technologies Agricultural and Biological Sciences (S. Trdan, ed.).InTech Open Access Publisher. pp. 1-56.

Gonias ED, Oosterhuis DM and Bibi AC, 2008. Cotton growth and yield enhancement from the insecticide TrimaxTM. Am. J. Plant Sci. 2: 60-62.

Henderson CF and Tilton EW, 1955. Tests with acaricides against the brow wheat mite. J. Econ. Entomol. 48:157-161. https://doi.org/10.1093/jee/48.2.157

Jesse CR, Savegnago L and Nogueira CW, 2007. Role of nitric oxide/cyclic GMP/K(+) channel pathways in the antinociceptive effect caused by 2,3-bis (mesitylseleno) propenol. Life. Sci. 81:1694-1702.

Jones D, 2003. Plant viruses transmitted by whiteflies. Eur. J. Plant. Pathol. 109:195-219.

Jose L and Usha R, 2003. Bhendi yellow vein mosaic disease in India is caused by association of a DNA satellite with a begomovirus. Virol. 305:310-317. DOI: $10.1006 /$ viro.2002.1768 
Kadam DB, Kadam DR, Umate SM and Lekurwale RS, 2014. Bioefficacy of newer neonicotenoids against sucking insect pests of $\mathrm{Bt}$ cotton. Int. J. Plant. Protect. 2:415-419.

Khan MA, Wahid A, Ahmad M, Tahir MT, Ahmad M, Ahmad S and Hasanuzzaman M, 2020. World Cotton Production and Consumption: An Overview. In: Ahmad S., Hasanuzzaman M. (eds) Cotton Production and Uses. Springer, Singapore. https://doi.org/10.1007/978-981-15-1472-2_1

Kumar V, Kakkar G, McKenzie CL and Osborne LS, 2016. Effect of Foliar Application of Pyrifluquinazon on Bemisiatabaci (MED Whitefly) and Amblyseiusswirskii, 2016. Arthropod. Manage. Tests. 41(1): 1-2. DOI: 10.1093/amt/tsw135

Liu ZD, Li DM., Gong PY and Wu KJ, 2004. Life table studies of the cotton bollworm, Helicoverpaarmigera (Hübner) (Lepidoptera: Noctuidae), on different host plants. Environ. Entomol. 33:1570-1576.

Magsi F, Hussain LK, Ahmed CM, Bhutto Z, Channa N and Ahmed JA, 2017. Effectiveness of different synthetic insecticides against Bemisiatabaci (genn) on tomato crop. India: Akinik Publications. Int. J. Fauna Biol. 4: 6-9.

McLeod P and Rashid T, 2014. Toxicity of pyrifluquinazon against greenhouse whitefly on tomato produced in greenhouses. Adv. Entomol. 214(2): 115-119. DOI: $10.4236 /$ ae. 2014.23018

Muhammad A, Muhammad HB, Muhammad A and Muhammad AK, 2009. Efficacy of some insecticides against whitefly (BemisiatabaciGenn.) infesting cotton under field conditions. Pak. J. Life. Sci. 7:140- 143.

Muhammad W, Ahmad M and Ahmad I, 2020. Pollination Behaviour of Cotton Crop and Its Management. In: Ahmad S., Hasanuzzaman M. (eds) Cotton Production and Uses. Springer, Singapore. https://doi.org/10.1007/978-981-151472-2_10

Naveen NC, Chaubey R, Kumar D, Rebijith KB, Rajagopal R, Subrahmanyam B and Subramanian $\mathrm{S}, 2017$. Insecticide resistance status in the whitefly, Bemisiatabaci genetic groups Asia-I, Asia-II-1 and Asia-II-7 on the Indian subcontinent. Sci. Rep. 7:40634. https://doi.org/10.1038/srep40634

Pathania M, Arora PK, Pathania S and Kumar A, 2019. Studies on population dynamics and management of pomegranate aphid, Aphis Passerinipunicae
(Hemiptera: Aphididae) on pomegranate under semi-arid conditions of South-western Punjab. Sci. Hortic. 43(3):300-306.

Pathania M, Verma A, Singh M, Arora PK and Kaur N, 2020. Influence of abiotic factors on the infestation dynamics of whitefly, Bemisiatabaci (Gennadius 1889) in cotton and its management strategies in North-Western India. Int. J. Trop. Insect Sci.40:969-981.

Salazar-López NJ, Aldana-Madrid ML, SilveiraGramont MI and Aguiar JL, 2016. SpirotetramatAn alternative for the control of parasitic sucking insects and its fate in the environment. Insecticides Resistance. InTech. 41-54.

Smith AH and Nagle A, 2017. Effects of Pyrifluquinazon on Nymphal Stages of Bemisiatabaci MEAM1 (Hemiptera: Aleyrodidae). J. Insect Sci. 17(6): 1-4. https://doi.org/10.1093/jisesa/iex091

Smith H and Giurcanu M, 2013. Residual effects of new insecticides on egg and nymph densities of bemisiatabaci (Hemiptera: Aleyrodidae). Fla. Entomol. 96(2): 504-511. http://www.jstor.org/stable/23609338

Tariq K, Ali R, Butt ZA, Ali A, Naz G, Anwar Z, Ali A, Khursheed I, Gulzar A, Saeed S and Shah JA, 2016. Comparative efficacy of different insecticides alone and along with adjuvant against cotton whitefly Bemisiatabaci in Multan, Pakistan. AmEurasian. J. Agric. Environ. Sci. 16:1424-1430.

Tsai JH and Wang JJ, 2001. Effects of host plants on biology and life table parameters of Aphid spiraecola (Homoptera: Aphididae). Environ. Entomol. 30:45-50.

Youngman RR, Leigh TF, Kerby TA, Toscano NC and Jackson CE, 1990. Pesticides and cotton: effect on photosynthesis, growth, and fruiting. J. Econ. Entomol. 83(4): 1549-1557.

\section{Contribution of Authors}

Muhammad W: Designed the project and recorded data

Ammar M: Provided research material and conducted trials at different places

Mukhtar T: Contributed in literature review and article write up.

Hamza AM: Contributed in literature review and article write up. 